\title{
Bleeding air ambulance patients: an audit of tranexamic acid use
}

\author{
Adam Chesters", Ainsley Heyworth, James Arthur \\ From London Trauma Conference 2014 \\ London, UK. 9-12 December 2014
}

\section{Background}

Essex and Herts Air Ambulance Trust (EHAAT) teams have carried tranexamic acid (TXA) on all missions since 2012. The CRASH-2 trial demonstrated a reduction in all-cause mortality in trauma patients thought to have significant haemorrhage.

\section{Methods}

A retrospective audit was undertaken of all EHAAT missions during 2013. All cases where the patient was classed as 'positive' by the Regional Major Trauma Network triage tool $(\mathrm{MT}+\mathrm{ve})$ were included. The primary outcome was the administration of the first bolus dose of $1 \mathrm{~g}$ TXA (or paediatric appropriate dose). Compliance was defined as 'patients thought to have significant haemorrhage received TXA'. Compliance with the local ambulance service guidelines (trauma patients with hypotension or tachycardia) was also reviewed.

\section{Results}

84 patients were identified as MT+ve, and of these 15 received TXA. There were 8 patients documented as having significant haemorrhage. All of these patients received TXA. Blunt trauma accounted for all but 2 of the patients. The mean initial pulse rate of those patients who received TXA was 107 beats per minute (95\% CI $=/$ - 19.9) and the mean pulse rate of those patients who did not receive TXA was 87 beats per minute $(95 \% \mathrm{CI}+/-6.2)(\mathrm{p}<0.01)$. The mean first recorded systolic blood pressure was $101 \mathrm{mmHg}(95 \%$ $\mathrm{CI}+/$ - 15.3) for those patients receiving TXA vs. 128 mmHg (95\% CI +/- 6.6) for those who did not (p 0.01).

* Correspondence: adam.chesters@ehaat.uk.com

Essex and Herts Air Ambulance Trust, Earls Colne, United Kingdom

\section{Conclusions}

We have demonstrated that $100 \%$ of patients received TXA if attended by our service and thought to be significantly bleeding following trauma. We have also demonstrated alignment with the local ambulance service guidelines pertaining to the use of TXA. Further clarification is required around the indications for TXA in all trauma patients, and EHAAT requires a specific standard operating procedure to ensure that practice is evidencebased and effective.

Published: 11 September 2015

doi:10.1186/1757-7241-23-S2-A2

Cite this article as: Chesters et al:: Bleeding air ambulance patients: an audit of tranexamic acid use. Scandinavian Journal of Trauma,

Resuscitation and Emergency Medicine 2015 23(Suppl 2):A2.
Submit your next manuscript to BioMed Central and take full advantage of:

- Convenient online submission

- Thorough peer review

- No space constraints or color figure charges

- Immediate publication on acceptance

- Inclusion in PubMed, CAS, Scopus and Google Scholar

- Research which is freely available for redistribution
() Biomed Central 